\title{
Regulation of growth and metabolism
}

David M Sabatini

From Metabolism, Diet and Disease 2014: Cancer and metabolism

Washington DC, USA. 28-30 May 2014

mTOR is the target of the immunosuppressive drug rapamycin and the central component of a nutrientand hormone-sensitive signaling pathway that regulates cell growth and proliferation. We now appreciate that this pathway becomes deregulated in many human cancers and has an important role in the control of metabolism and aging. We have identified two distinct mTOR-containing proteins complexes, one of which regulates growth through $\mathrm{S} 6 \mathrm{~K}$ and another that regulates cell survival through Akt. These complexes, mTORC1 and mTORC2, define both rapamycin-sensitive and insensitive branches of the mTOR pathway. I will discuss new results from our lab on the regulation and functions of the mTORC1 and mTORC2 pathways.

Published: 28 May 2014

doi:10.1186/2049-3002-2-S1-O20

Cite this article as: Sabatini: Regulation of growth and metabolism.

Cancer \& Metabolism 2014 2(Suppl 1):O20.

Whitehead Institute for Biomedical Research; Howard Hughes Medical Institute and Department of Biology, MIT; Broad Institute of Harvard and MIT; The David H Koch Institute for Integrative Cancer Research at MIT, Cambridge, MA, USA
(0) 2014 Sabatini; licensee BioMed Central Ltd. This is an Open Access article distributed under the terms of the Creative Commons Attribution License (http://creativecommons.org/licenses/by/4.0), which permits unrestricted use, distribution, and reproduction in any medium, provided the original work is properly cited. The Creative Commons Public Domain Dedication waiver (http:// creativecommons.org/publicdomain/zero/1.0/) applies to the data made available in this article, unless otherwise stated. 